\title{
Nexus Between Financial Development, FDI, Globalization, Energy Consumption and Environment: Evidence From BRI Countries
}

\section{OPEN ACCESS}

Edited by:

Hooi Hooi Lean,

Universiti Sains Malaysia (USM),

Malaysia

Reviewed by:

Ilhan Ozturk,

Çağ University, Turkey

Hayot Berk Saydaliyev,

Suleyman Demirel University,

Kazakhstan

Dervis Kirikkaleli,

European University of Lefka, Turkey

Shujah ur Rahman,

University of Education Lahore,

Pakistan

*Correspondence:

Shah Saud

saud_mrd@yahoo.com

Specialty section:

This article was submitted to

Sustainable Energy Systems and

Policies,

a section of the journa

Frontiers in Energy Research

Received: 10 May 2021

Accepted: 05 August 2021

Published: 16 September 2021

Citation:

Lu J, Imran M, Haseeb A, Saud S, Wu M, Siddiqui F and Khan MJ (2021)

Nexus Between Financial

Development, FDI, Globalization,

Energy Consumption and

Environment: Evidence From

BRI Countries.

Front. Energy Res. 9:707590.

doi: 10.3389/fenrg.2021.707590

\author{
Jie Lu ${ }^{1}$, Muhammad Imran ${ }^{2,3}$, Abdul Haseeb $^{4}$, Shah Saud ${ }^{5,6 *}$, Mengyun $W^{2}{ }^{2}$, Faiza Siddiqui ${ }^{2}$ \\ and Muhammad Jalal Khan ${ }^{7}$
}

${ }^{1}$ School of Management, Jiangsu University, Zhenjiang, China, ${ }^{2}$ School of Finance and Economics, Jiangsu University, Zhenjiang, China, ${ }^{3}$ Department of Management Sciences, ILMA University, Karachi, Pakistan, ${ }^{4}$ Department of Management Sciences, University of Haripur, Haripur, Pakistan, ${ }^{5}$ School of Management and Economics, Beijing Institute of Technology, Beijing, China, ${ }^{6}$ Institute of Business Studies, Kohat University of Science and Technology, Kohat, Pakistan, ${ }^{7}$ School of Economics and Management, Chang'an University, Xi'an, China

This study explores the nexus between foreign direct investment, financial development, energy consumption, economic growth and globalization for a selected panel of Belt and Road Initiative (BRI) countries over the period 1990-2016. After employing appropriate panel unit root tests, the Westerlund co-integration test, the DSUR long-run panel estimation approach and the Dumitrescu-Hurlin panel causality test, the results reveal a significant longrun relationship among the analyzed variables. The DSUR results show that energy consumption is boosted by 0.023 and $0.790 \%$ when a $1 \%$ rise occurs in foreign direct investment and economic growth. A $1 \%$ increase in financial development and globalization reduces energy consumption by 0.049 and $0.621 \%$, respectively. We also found bidirectional relationships of energy consumption with financial development and foreign direct investment with globalization for the selected sample of our study. A unidirectional causal relationship exists, moving from energy consumption towards both financial development and foreign direct investment. An increase in FDI, the introduction of energy-efficient technology, and development of the financial sector lead to sustainable economic growth. The findings reveal the need to formulate policies that promote energy efficiency among Belt and Road (BR) countries. The policy implications of this study are presented in the Conclusion.

Keywords: energy consumption, FDI, financial development, DSUR, belt and road initiative

\section{INTRODUCTION}

In the current globalization era, the debate on energy policy and its regulation is considered a critical area of research by practitioners and academics. Energy consumption is an integral part of economic development (Belke et al., 2011) and social and sustainable development (Kahouli, 2017). Due to the rise in world economic growth, the gap between demand and energy supply has increased rapidly in recent years, thereby increasing energy insecurity, including in BRI counties. Financial development motivates the adoption of advanced energy-efficient and environment-friendly technologies, resulting in a better global environmental quality. 
Recently, the world economy rapidly grew excessively, which can also affect energy consumption level, and securing an appropriate energy supply level is also then a challenge for world economies: the global economy grew by 22.9 times between 1971 and 2015, and, along with economic growth, total energy consumption levels in 2015 were about 2.2 times their 1971 level $^{1}$.

In recent decades, several studies have investigated the relationship between energy and economic development. In most of these, an increase in energy consumption has been linked to economic growth (Saud and DanishChen, 2018). Thus, it is also possible to observe a link between energy consumption and financial development (Çoban and Topcu, 2013). Similarly, the financial sector performs a crucial role in the stability and development of an economy. 'Financial development' mainly refers to an increase in the financial activities of a country, such as an increase in foreign direct investment (FDI), an increase in the provision of credit to the private sector, the financial sector, and to the private sector by the banks, or an increase in stock market activities of an economy. Financial development plays a crucial role in a country's financial systems, increasing economic efficiency but also energy consumption levels (Sadorsky, 2011; Islam et al., 2013c; Husaini and Lean, 2015; Le and Ozturk, 2020; Baloch et al., 2021; Godil et al., 2021.

Three different avenues exist to explain the financial development and energy consumption nexus. First, financial development encourages more inflows of FDI, which lead to enhancing energy consumption and economic growth. Second, financial development causes financial sector development, which leads to efficient financial intermediation approaches to more consumer credit which surges in purchases of 'big-ticket' items. Third, the development of capital markets and financial markets facilitates more reserves in economies, enhancing energy consumption (Zhang, 2011).

Many empirical studies have considered other factors that can affect the turning point of the Environmental Kuznets Curve (EKC) and environmental quality. One of these factors is financial development (FD) which has become the focus of environmental studies (Adebayo et al., 2021a; Adebayo and Kirikkaleli, 2021; Kirikkaleli et al., 2021; Rehman et al., 2021). FD may facilitate investments such as providing more funds to new firms, which may bring more opportunities to establish or upgrade the renewable energy sector. FD attracts more FDI, leading to technological innovations and thus assisting in reducing energy consumption (Chang, 2015). It is a fact that FDI is one of the reliable sources that boosts domestic production capacities, brings upgraded technologies, and increases investment through finance provision (Sirin, 2017). Therefore, researchers believe that only superior knowledge and management practices can sustain and give the edge to international enterprises undertaken on foreign soil, and probably through FDI (Doytch and Narayan, 2016). Further,

${ }^{1}$ IEA. World Energy Statistics and Balances. Paris: International Energy Agency; 2017. there is ample literature that explores the nexus between FDI and energy consumption. FDI can enhance energy consumption by developing and expanding the industrial, logistics and manufacturing sectors, where energy is considered the backbone of the industrialized process. However, this important area needs further investigation in view of updated data and advances in econometrics techniques .

Investigation of energy consumption, FDI and financial development may clarify controversy surrounding the BRI, which China first proposed in 2013. The BRI comprises two routes: the Silk Road Economic Belt and the 21st Century Maritime Silk Road. This initiative seeks to connect infrastructure networks and to build trade between Asia and Europe and Africa along the ancient Silk Road routes. Therefore, it is one of the main priorities and important pillars of the BRI to strengthen energy cooperation along the BRI routes (NDRC NOFA M, 2015; Khan and Ozturk, 2020; Adebayo et al., 2021a). The BRI's link with the energy sector is not without controversy, because this may also have other impacts on productivity, such through as a rise in financial provision and infrastructure development. The BRI will enhance energy security in China and its partner countries through improving production, energy supply, and energy efficiency gain.

However, the international community tends to believe that China's outdated industries will be transferred to other countries through this initiative, resulting in a decline in their environmental quality and an increase in energy consumption (Pieter, 2017). This counter-view of the BRI may prevent or discourage some economies from participating in the Initiative. This would also stop those countries from introduction of technological advances, and finance- and expertise-related activities (Han et al., 2018).

In the light of this discussion, this study investigates the longrun relationship between FDI, energy consumption (EC) and FD for a panel of BRI countries for the period 1990-2016.

This study makes two contributions. Firstly, numerous timeseries and panel studies have investigated such relationships (Sadorsky, 2010; Sadorsky, 2011; Islam et al., 2013a; Ozturk and Acaravci, 2013; Shahbaz et al., 2013; Hu et al., 2020; Rehman et al., 2021), but to the authors' knowledge, the research remains scant in many respects, such that studies have not yet been undertaken in the context of BRI countries, which potentially provide an essential panel for such an investigation. Secondly, prior empirical literature has used panel data analysis techniques and combined-countries analysis, while this study uses a unique set of country-wise, long-run estimations. This study uses the second-generation DSUR estimator approach and takes the most extended data available for the analyzed variables.

This study thus assists both China and other BRI countries identify and understand any potential adverse impacts of the Initiative, thereby helping to provide practical information for policymakers.

The rest of the paper is organized as follows. Literature Review provides the literature review. Data and Methodology discusses the data and methodology. Results and Discussion provides the estimated results and discussion of them. The final section concludes the paper and provides implications. 


\section{LITERATURE REVIEW}

The BRI has attracted global attention (Godement, 2015), and there is no doubt that the BRI will have a significant impact on economies around the world in areas such as finance, the environment, economies, energy, education and politics (Palit, 2017). As with the significance of other economic variables, FD can also positively stimulate and brings changes to an economy, in that it assists the easier availability of financial capital, it promotes global investment, facilitates ready availability of energy-efficient appliances, minimizes financial risks, reduces borrowing costs, and enhances transparent economic transactions between borrowers and lenders. All such stimulation of economic activities can affect energy consumption with fixed investment in different economies (Saud and DanishChen, 2018). FD provides liquidity for the establishment of efficient projects, and energy also plays an integral part in the smooth running of financial sector. Development in the financial sector can boost liquidity for investment, industrial expansion, and facilitate new infrastructure, significantly affecting energy consumption (Islam et al., 2013a). Hence, this study categorizes the empirical literature based on two strands: the first strand employs time-series data; the second uses a panel countries data framework.

Shahbaz and Lean probe the energy-finance nexus in Tunisia for the period 1971-2008. The ARDL and the Johansen co-integration tests were adopted for data analysis. The results show the presence of a long-run relationship between energy consumption and finance. A bidirectional causal relationship between the two variables was also detected (Shahbaz and Lean, 2012).

The feedback effect between financial development and energy consumption has been detected in Malaysia, while, in the short run, energy consumption through FD is shown by Granger causality analysis (Tang and Tan, 2014). Another similar study probes the presence of a long-run association between FDI, relative price, economic growth, FD and energy consumption by applying the Johansen and Juselius co-integration approach; this study presented a bidirectional link between growth and energy consumption and a unidirectional causal link from financial development towards economic growth. Another study investigated the long-run relationship between energy and finance for Pakistan for 1972-2012 (Komal and Abbas, 2015; Adebayo et al., 2021b). The findings of this empirical work revealed the significant positive influence of financial development on energy consumption.

More recently, Saudi Arabia has examined the energy-finance nexus 1971-2011 (Mahalik et al., 2017); the study findings explore the presence of a one-way causal link from financial development to energy demand. Similarly, Kahouli specifies that escalation in FD accelerates energy consumption, which adversely stimulates the real output growth in Israel (Kahouli, 2017).

In panel-country analysis, a direct relationship has been observed between energy consumption and FD for a panel of 22 developing countries over the period 1990-2006 (Sadorsky, 2010). The findings of the study reveal the positive relationship between the explanatory variables.

Another study Husaini and Lean (2015) explores how electricity consumption, output and price are co-integrated in the long run. However, the relationship between electricity consumption and output is positive. In the long run, the study has found a unidirectional causality from manufacturing output to electricity consumption. The findings indicate that the development of the manufacturing sector stimulates a more significant energy demand.

$\mathrm{Xu}$ probes the finance and energy relationship for 29 Chinese provinces during 1999-2009. This study employs the GMM approach, and the findings show the positive relationship between consumption of energy and FD (Xu, 2012).

Another similar study, focusing on a panel of GCC countries, investigates the long-run association between economic growth, trade openness, FD, urbanization and energy consumption by applying the Pedroni co-integration approach (Al-mulali and Lee, 2013). The findings reveal that trade openness, FD, urbanization and economic growth positively impact energy consumption. Further, a two-way causality exists between FD and growth, energy consumption and growth, trade openness and economic growth, openness and FD, and openness and urbanization. A one-way causal relationship is detected from FD towards energy consumption and urbanization towards energy consumption.

A study examines the effects of financial development on energy consumption from 1971 to 2009 (Tang and Tan, 2014). The findings report the existence of a bidirectional causal link between energy and FD. However, Chang argues that FD can bring opportunities in regard to renewable energy sector expansion by providing more funds for innovative firms (Chang, 2015).

Furuoka studies the association between finance and energy consumption in Asia from 1980 to 2012, employing a panel cointegration test (Furuoka, 2015; He et al., 2021; Li et al., 2021; Teng et al., 2021). The finding confirms the long-run association between finance and energy consumption. Further, the one-way causality relationship is noticed, running towards financial development from energy consumption. Hence, the rise in energy consumption may motivate the acceleration of FD in Asia. It also confirms that FD in financial sector development reduces energy consumption in BRICS countries (Ahmed, 2017).

Yet another study proposes that increased energy efficiency can minimize energy consumption, increasing financial development in China (Fan et al., 2017; Adebayo et al., 2021c).

\section{DATA AND METHODOLOGY}

The analysis of this study is based on 59 BRI countries ${ }^{2}$. In recent times the Chinese State Information Center has hosted 71 BRI countries (Krane, 2018). However, the selection of countries and the choice of the period (1990-2016) were constrained by data appropriateness and accessibility, which reduced our sample size to only 59 BRI countries. The main variables of the study are

\footnotetext{
${ }^{2}$ Albania, Azerbaijan, Armenia, Bahrain, Belarus, Bangladesh, Bosnia and Herzegovina, Bulgaria, Brunei, Cambodia, Colombia, China, Czech Republic, Croatia, Egypt Arab Republic, Ethiopia, Estonia, Georgia, Hungary, Indonesia, India, Iran, Iraq, Islamic Republic, Israel, Jordan, Kazakhstan, Kuwait, Kyrgyz Republic, South Korea, Lebanon, Macedonia, Mongolia, Malaysia, Moldova, Myanmar, Morocco, New Zealand, Nepal, Oman, Panama, Pakistan, Poland, Philippines, Qatar, Russian Federation, Romania, Singapore, Saudi Arabia, Slovak Republic, South Africa, Slovenia, Sri Lanka, Thailand, Tajikistan, Turkey, United Arab Emirates, Ukraine, Vietnam, Yemen Republic.
} 
TABLE 1 | Variables, measure, data source, and time span.

\begin{tabular}{|c|c|c|c|c|}
\hline Variable name & Acronym & Measure & Data source & Time span \\
\hline Foreign direct investment & FDI & The net inflow of foreign direct investment (\% of GDP) & WDI & 1990-2016 \\
\hline Financial development by financial sector & $\mathrm{FDF}_{\mathrm{S}}$ & Domestic credit by financial sector (\% of GDP) & WDI & 1990-2016 \\
\hline Financial development by banks & $\mathrm{FD}_{\mathrm{B}}$ & Domestic credit to the private sector by banks (\% of GDP) & WDI & 1990-2016 \\
\hline Energy consumption & EC & $\mathrm{kg}$ of oil equivalent per the capita & WDI & 1990-2016 \\
\hline Economic Growth & GDP & Gross domestic product per capita (constant 2010 US\$) & WDI & 1990-2016 \\
\hline Globalization & GLO & Index of globalization & KOF Index & 1990-2016 \\
\hline
\end{tabular}

World Development Indicator (WDI, 2017).

energy consumption (EC), financial development (FD) and foreign direct investment (FDI). The data are collected from the World Development Indicator (WDI, 2017). FDI is measured by the net inflow of foreign direct investment (\% of GDP), FD is gauged by domestic credit to the private sector (\% of GDP), domestic credit provided to the private sector by banks (\% of GDP), and domestic credit provided by the financial sector (\% of GDP) (Sun et al., 2020). GDP per capita (constant 2010 US\$) represents economic growth. EC denotes energy use (kg of oil equivalent per capita). Globalization has been expressed through an index of globalization (Pohekar and Ramachandran, 2004; Saud and DanishChen, 2018).

The selection of variables for our study is based on several prior empirical studies. To facilitate the interpretation of the estimated coefficients, we transformed the variables into their logarithms. This also controls the heteroskedasticity issue and reduces differences in the heterogeneous panel data. The variables and their measure, data sources, frequency, measure, data sources are presented in Table $\mathbf{1}$.

\section{Methodology}

This study empirically explores the nexus among the analyzed variables, i.e., financial development, FDI, growth, energy consumption, and globalization, for a heterogeneous panel of BRI countries. FD is the key factor for economic development, because it promotes the financial efficiency of an economy (Sadorsky, 2011). Economic growth and development rise when well-developed financial sectors exist in a country (Nasreen et al., 2017). Therefore, an economy's well-developed financial sector and financial structure bring FDI into the region through globalization and affect energy consumption and the environment through various effects. Globalization stimulates an economy's competitive advantages and brings changes and economic prosperity through international collaboration and trade. It affects domestic production factors and its composition has effects on energy and the environment (Ling et al., 2015). Based on this discussion and the empirical works of Shahbaz et al. (2016b) and Ahmed (2017), we propose long-run Eq. 1:

$$
E C=f(F D, F D I, G D P, G L O)
$$

Where FD represents financial development; FDI shows foreign direct investment; GDP is the economic growth; GLO indicates globalization; and EC indicates energy consumption. The analyzed variables are taken in their natural logarithms in order to acquire consistent results. The log-linear form can rewrite Eq. 1 as follows:

$$
\begin{aligned}
\operatorname{InEC}_{2 i t}= & \beta_{0}+\beta_{1 t}\left(\operatorname{InFD}_{i t}\right)+\beta_{2 t}\left(\operatorname{InGDP}_{i t}\right)+\beta_{3 t}\left(\operatorname{InFDI}_{i t}\right) \\
& +\beta_{4 t}(\operatorname{InGLO} i t)+\lambda_{i t}
\end{aligned}
$$

Where $t$ represents the number of periods (i.e., $1,2,3, \ldots . \mathrm{n}$ ); $i$ indicate the number of countries (i.e., $1,2,3, \ldots \mathrm{n}$ ); InEC is the logarithm of energy consumption (dependent variable); InFD and InFDI are the logarithms of FD and FDI, respectively (independent variables); InGDP is the logarithm of economic growth; and InGLO is the logarithm of the globalization index; $\lambda$ represents the error term; $\beta_{0}$ shows the slope-intercept; $\beta_{1 t}, \beta_{2 t}$, $\beta_{3 t}$, and $\beta_{4 t}$ are the coefficient estimates of FD, GDP, FDI, and GLO, respectively. We expect $\beta_{1}$ and $\beta_{4}$ will be negative, and $\beta_{2}$ and $\beta_{3}$ positive.

\section{RESULTS AND DISCUSSION}

Before checking and analyzing the stationarity of the data, it is imperative to check it for cross-sectional dependence in the context of heterogeneous panels. To this end, and Pesaran (2007) CD tests have been implied, which are more consistent and reliable for panel data. The outcomes of the CD tests are noted in Table 2, which confirms the presence of cross-sectional dependence in the panel data, since the probability value is below 0.09 . Hence, the findings show cross-sectional dependency for FDI, EC, economic growth, globalization and FD.

\section{Panel Unit Root Test}

The econometric analysis starts with the panel unit root test to check the level of stationarity of the data. Several panel unit root tests proposed by prior literature, such as the first-generation panel unit root tests [i.e., Levin Lin Chu (LLC), and Hadri, Breitung] and the second-generation panel unit root tests (i.e., IM Pesaran Shin, Fisher PP, Fisher ADF test, and CIPS and $\mathrm{CADF}$ ). The first-generation estimator may not be appropriate for reliable results due to the low power of the test (O'Connell, 1998). Therefore, this study prefers to employ the CIPS and CADF tests established by Pesaran et al. (2008) for panel unit root confirmation. The results of the panel unit root tests are presented in Table 3, and show that the evaluated variables become stationary at first differences [I (1)] and unit root at levels. Similarly, researchers examine the impacts of Pakistani rupee volatility on monthly energy imports based on the nonlinear autoregressive distributed lag (NARDL) estimations. Augmented Dickey-Fuller and Phillips-Perron 
TABLE 2 | Test for cross-sectional dependence.

\begin{tabular}{|c|c|c|c|c|}
\hline \multirow[t]{2}{*}{ Variables } & \multicolumn{2}{|c|}{ Pesaran CD } & \multicolumn{2}{|c|}{ Scaled LM } \\
\hline & Statistic & Probability & Statistic & Probability \\
\hline LnENERGY & $5.152^{\star \star \star}$ & 0.000 & $173.15^{\star \star \star}$ & 0.000 \\
\hline LnFDFS & $3.71^{\star \star \star}$ & 0.000 & $140.83^{\star \star \star}$ & 0.000 \\
\hline LnFDB & 1.98 & 0.047 & $118.38^{\star \star \star}$ & 0.000 \\
\hline LnGLOB & $101.75^{\star \star \star}$ & 0.000 & $271.50^{\star \star \star}$ & 0.000 \\
\hline LnFDI & $12.73^{\star \star \star *}$ & 0.000 & $46.60^{\star \star \star}$ & 0.000 \\
\hline LnGDP & $13.19^{\star \star \star}$ & 0.000 & $143.86^{\star \star \star}$ & 0.000 \\
\hline
\end{tabular}

Note: ${ }^{* * *}$ and ${ }^{* * *}$ shows significance at 1, 5, and 10\% significance levels.

\begin{tabular}{|c|c|c|c|c|}
\hline \multirow[t]{2}{*}{ Variables } & \multicolumn{2}{|r|}{ CIPS } & \multicolumn{2}{|r|}{ CADF } \\
\hline & Level & First Difference & Level & First Difference \\
\hline LnENERGY & -1.212 & $-2.939^{\star \star \star}$ & -1.681 & $-3.588^{\star \star \star}$ \\
\hline LnFDFS & -1.512 & $-4.377^{\star \star \star}$ & -1.748 & $-3.173^{\star \star \star}$ \\
\hline LnFDB & -1.722 & $-4.239^{\star \star \star}$ & $-2.065^{3}$ & $-3.230^{1}$ \\
\hline LnGLOB & $-3.155^{\star \star \star}$ & $-4.848^{\star \star \star}$ & $-2.443^{\star \star \star}$ & $-3.750^{\star \star \star}$ \\
\hline LnFDI & $-3.484^{\star \star \star}$ & $-5.631^{\star \star \star}$ & $-2.870^{\star \star \star}$ & $-4.415^{\star \star \star}$ \\
\hline LnGDP & -1.994 & $-3.972^{\star \star \star}$ & $-2.543^{\star \star \star}$ & $-3.193^{\star \star \star}$ \\
\hline
\end{tabular}

Note: ***, ** and *, denote the statistical significance at 1, 5, and 10\% levels, respectively.

tests were used to conduct unit root testing, and the bound testing approach was used to examine the long-term cointegration (Saqib et al., 2021).

\section{Westerlund Panel Co-Integration Test}

After confirming the stationarity in the data at the first differences, in Table 4 we find the co-integration among the analyzed variables. This study used the Westerlund panel co-integration test proposed by Westerlund (2007). This method detects the existence of heterogeneity in the data and provides more consistent and robust results. The Westerlund co-integration results infer that both group and probability statistics are significant at a $1 \%$ significance level. The finding suggests that the null hypothesis of no co-integration is rejected. Thus, co-integration exists among the analyzed variables, i.e., EC, FDI, FD, GDP and GLO.

\section{DSUR Long-Run Estimation Test}

The key inference of empirical work is to analyze the long-run estimations among the examined variables. This study employed the second-generation estimator DSUR established by Mark et al. (2005). The DSUR estimator is a good predictor and provides consistent normal distribution, even if N's value is smaller than the value of T. Moreover, it accounts for cross-sectional dependence and heterogeneity. Prior research also used the same model for similar and diverse panel studies (Haseeb et al., 2019; Saud et al., 2019; Shujah-Ur-Rahman et al., 2019). This approach estimates the long-run coefficient of EC, FDI, GDP, FD, and GLO. The DOLS approach is employed for country-wise analysis, along with the DSUR approach for panel data analysis. The results of the DSUR panel long-run estimation and DOLS approach are presented in Tables 5, 6, respectively.
TABLE 4 | Results of Westerlund panel co-integration test.

\begin{tabular}{|c|c|c|c|c|c|c|}
\hline \multirow[t]{2}{*}{ Test } & \multicolumn{3}{|c|}{ MODEL-1 (FDFS) } & \multicolumn{3}{|c|}{ MODEL-2 (FDB) } \\
\hline & Value & Z-Value & $p$-Value & Value & Z-Value & $p$-Value \\
\hline Group-T & $-2.315^{\star \star \star}$ & -2.509 & 0.006 & -2.123 & -1.074 & 0.141 \\
\hline Group-a & -5.258 & 4.991 & 1.000 & -4.503 & 5.807 & 1.000 \\
\hline Panel-T & $-16.31^{\star \star \star}$ & -3.076 & 0.001 & $-16.65^{\star \star \star}$ & -3.341 & 0.000 \\
\hline Panel- $\alpha$ & -6.327 & -0.223 & 0.412 & -6.522 & -0.429 & 0.334 \\
\hline
\end{tabular}

TABLE 5 | Results from panel DSUR estimation.

Dependent Variable $=$ Energy consumption

\begin{tabular}{|c|c|c|c|c|c|c|}
\hline \multirow[t]{2}{*}{ Variable } & \multicolumn{3}{|c|}{ MODEL-1(FDFS) } & \multicolumn{3}{|c|}{ MODEL-2 (FDB) } \\
\hline & Coeff. & t-Statistics & Prob.* & Coeff. & t-Statistics & Prob.* \\
\hline LnFDFS & $-0.049^{\star \star \star}$ & -3.360 & 0.001 & - & - & - \\
\hline LnFDB & - & - & - & $-0.026^{\star *}$ & -1.800 & 0.072 \\
\hline LnGLOB & $-0.621^{\star \star \star}$ & -8.720 & 0.000 & $-0.646^{\star \star \star}$ & -8.980 & 0.000 \\
\hline LnFDI & $0.023^{\star \star \star}$ & 2.650 & 0.008 & $0.025^{\star \star \star}$ & 2.920 & 0.004 \\
\hline LnGDP & $0.790^{\star \star \star}$ & 60.00 & 0.000 & $0.794^{\star \star \star}$ & 59.46 & 0.000 \\
\hline Constant & $1.441^{\star \star \star}$ & 15.60 & 0.000 & $1.428^{\star \star \star}$ & 15.04 & 0.000 \\
\hline R-square & 0.778 & - & - & 0.777 & - & - \\
\hline F-statistic & 1398 & - & - & 1389 & - & - \\
\hline Prob. & 0.000 & - & - & 0.000 & - & - \\
\hline
\end{tabular}

\section{Heterogeneous Panel Causality Test}

The DSUR panel long-run estimation results are not appropriate for offering sufficient evidence about the direction of the causal relationship between the analyzed variables for relevant policymaking. Knowledge about the causal link between EC, FDI and FD can assist in crafting applicable energy-finance policies in regions and these guarantee sustainable economic growth. This study employed the panel causality approach for testing the null hypothesis of the homogeneous non-causality counter to the alternative hypothesis of heterogeneous noncausality (Dumitrescu and Hurlin, 2012). The significance of using this approach is that it permits heterogeneous unrestricted coefficients through CD and dissimilar log structures. This technique comprises two statistics, i.e., $\mathrm{Z}$ bar-statistics demonstrate the standard normal distribution of the test, and the $\mathrm{W}$ bar-statistics show the average statistics. The DH panel causality test results are stated in Table 7 . The empirical findings presented in this study are more robust and reliable because we employ appropriate estimation approaches.

\section{DSUR Long-Run Estimates}

The key empirical results of DSUR long-run estimation are displayed in Table 5. It is worth mentioning that, in reference to the probability values and t-statistics values, the coefficient estimates of all the explanatory variables are statistically significant. At a glance, it is seen that FDI promotes energy consumption in BRI countries. FDI has highly significant (at 1\% level) and positive effects on energy consumption. The magnitudes of 0.0232444 and 0.0255713 (respectively) suggest 
TABLE 6 | Results of PMG ARDL Panel estimation.

\begin{tabular}{|c|c|c|c|c|c|c|}
\hline \multirow[t]{2}{*}{ Variable } & \multicolumn{3}{|c|}{ Model-1 (FDFS) } & \multicolumn{3}{|c|}{ Model-1 (FDB) } \\
\hline & Coeff. & t-Statistic & Prob.* & Coefficient & t-Statistic & Prob.* \\
\hline LnFDFS & $-0.061^{\star}$ & -4.538 & 0.000 & - & - & - \\
\hline LnFDB & - & - & - & $-0.123^{\star}$ & -7.514 & 0.000 \\
\hline LnGLOB & $-1.269^{\star}$ & -10.519 & 0.000 & $-1.087^{\star}$ & -11.023 & 0.000 \\
\hline LnFDI & $0.029^{\star}$ & 3.623 & 0.000 & $0.049^{\star}$ & 6.381 & 0.000 \\
\hline LnGDP & $0.339^{*}$ & 5.866 & 0.000 & $0.554^{*}$ & 14.846 & 0.000 \\
\hline S.E. of regression & 0.046 & - & - & 0.039 & - & - \\
\hline In likelihood & 3209.581 & - & - & 3179.176 & - & - \\
\hline Akaike info. criterion & -3.581 & - & - & -3.394 & - & - \\
\hline Hannan-Quinn criter. & -3.132 & - & - & -2.798 & - & - \\
\hline
\end{tabular}

Note: * specifies the level of rejection at the $1 \%$ significance level.

that a $1 \%$ rise in FDI can raise the EC by 0.023 and $0.025 \%$, respectively, in Models 1 and 2. It captures that FDI inflows are the key factor behind causing high energy consumption in the BRI regions. Our empirical result is consistent with the prior empirical literature: for instance, Lee and Wan (2013) for G20; Islam et al. (2013a) for Malaysia; and Alam et al. (2015) for SAARC countries. However, our result is not consistent with Farhani and Solarin (2017) for the US. FDI inflows motivate foreign investors to set up new businesses or expand their current companies in the host country, resulting in high energy demand and consumption in the area. Moreover, FDI inflow may bring inadequate energy consumption technology, lack of skills, high population mobility, and insufficient information transfer from one country, all of which increase energy consumption. The attraction of FDI into the economy increases industrial operations, production and energy consumption; however, the economic development of the economy rises. Hence FDI inflows positively impact EC in BRI countries.

The results in the Table show that FD affects EC negatively and significantly. It implies that FD does not harm the environment by reduction in EC. If all else is the same, a $1 \%$ rise in FD can reduce EC by $-0.049 \%$ and $-0.026 \%$, respectively, in Models 1 and 2. In other words, the negative estimated coefficient shows that FD has a marginal decrease in the consumption level of energy in these countries. The proxies used in Models 1 and 2 for FD significantly negatively affect EC in BRI countries. On a broader note, this confirmation is similar with Alam et al. (2015) for South Asian Association for Regional Cooperation countries, Farhani and Solarin (2017), for India, and Long et al. (2017) for the US. However, it is not in line with Liu et al. (2018) for China and Saud and DanishChen (2018) for China.

In the case of a solid financial system, financial institutions may quickly provide more debt at a low rate to their customers for investment activities, innovative energy-efficient projects, and research and development ( $R \& R$ and $R \& D)$ in regions, resulting in reduced EC (Solarin et al., 2017).

The facilitation of energy-saving and $\mathrm{R} \& \mathrm{D}$ projects is closely linked with advanced energy-efficient technologies, reducing EC by its efficient utilization (Tamazian et al., 2009). The stimulation of the effective banking system leads to an efficient financial system of the different economies, which assists in the easier provision of debt or loans to customers or investors for boosting income levels, while fulfilling the demand for energy through its efficient utilization (Tang and Tan, 2014). Another possibility is careless consumption and investment of banking and financial sector debt money in unproductive activities in these regions. This means that an easy monetary policy enhances credit allocation to the financial sector or the banking sector, enhancing investment opportunities in energy-efficient projects in these regions.

The relationship between economic growth and energy consumption is highly significant (at a $1 \%$ significance level) and positive. The coefficients 0.7902 and 0.7945 show that, keeping other things constant, a $1 \%$ rise in economic growth can cause an increase in EC by -0.790 and $0.794 \%$, respectively. This empirical finding is similar to the determination reached for India (Shahbaz and Lean, 2012), but it is not identical to the conclusion reached for the US (Farhani and Solarin, 2017). High growth requires more energy consumption, because energy is one of the essential factors in producing goods and services (Shahbaz et al., 2016b). Our result is also similar to the view of Shahbaz and Lean (2012) that the expansion of industrial activities and economic activities such as investment, production, purchasing, shopping, and consumption require more energy and contribute to the GDP. Further, old technologies, lack of skills, old production methods, the absence of knowledge, and lack of diversity in energy sources cause high EC in the BRI countries. The positive association between economic growth and EC shows that BRI countries are more concerned with their economic expansion, compromising their energy usage in return. FDI inflows switch agricultural land to manufacturing industries, which require more energy sources for production and manufacturing purposes, and thus EC rises.

The coefficient estimate of globalization with energy consumption is not harmful and is highly significant at a $1 \%$ significance level. The coefficients -0.6205 and -0.6466 imply that a $1 \%$ increase in globalization decreases EC by 0.62 and $0.64 \%$, respectively. The result implies that globalization reduces EC in the long run. This result is in line with for Brazil and Shahbaz et al. (2017b) for Singapore, but not in line with Shahbaz et al. (2016b) for India or Saud and DanishChen (2018) for China. Globalization is a slow process that reduces EC in the BRI countries. The negative link may be due to the 
TABLE 7 | Results from DOLS (country-wise).

\begin{tabular}{|c|c|c|c|c|c|c|c|c|}
\hline \multirow[t]{2}{*}{ Country Name } & \multicolumn{2}{|c|}{ FDFS } & \multicolumn{2}{|c|}{ FDI } & \multicolumn{2}{|c|}{ GLOB } & \multicolumn{2}{|c|}{ GDP } \\
\hline & Coefficient & $p$-value & Coefficient & $p$-value & Coefficient & $p$-value & Coefficient & $p$-value \\
\hline Albania & -0.2801 & 0.2099 & $-0.2234^{\star \star}$ & 0.0357 & -0.5155 & 0.7081 & $1.2569^{\star}$ & 0.0868 \\
\hline Armenia & $0.3602^{\star \star \star}$ & 0.0002 & $0.1523^{\star *}$ & 0.0156 & $-1.2502^{\star \star}$ & 0.0203 & $0.4888^{\star *}$ & 0.0439 \\
\hline Azerbaijan & $1.4995^{\star \star \star}$ & 0.0001 & $0.2237^{\star \star}$ & 0.0126 & $2.9277^{\star \star \star}$ & 0.0000 & $-1.1214^{\star \star \star}$ & 0.0007 \\
\hline Bahrain & $0.7090^{\star \star \star}$ & 0.0040 & $0.0373^{\star \star}$ & 0.0242 & $-3.4221^{\star \star \star}$ & 0.0034 & $2.0567^{\star \star \star}$ & 0.0006 \\
\hline Bangladesh & 0.1734 & 0.6070 & -0.0077 & 0.8652 & $-3.2241^{\star \star \star}$ & 0.0006 & $2.5505^{\star \star \star}$ & 0.0000 \\
\hline Belarus & $0.0992^{\star \star \star}$ & 0.0049 & $-0.4803^{\star \star \star \star}$ & 0.0000 & $2.1838^{\star \star \star}$ & 0.0077 & $-0.105^{\star}$ & 0.7296 \\
\hline Bosnia \& Herz. & -0.1395 & 0.4587 & $-0.1846^{\star}$ & 0.0772 & $0.5986^{\star}$ & 0.0637 & $0.6713^{\star \star \star}$ & 0.0001 \\
\hline Brunei Daru. & $-0.0577^{\star \star}$ & 0.0352 & $-0.1539^{\star \star}$ & 0.0194 & $1.7658^{\star \star \star}$ & 0.0000 & $0.2035^{\star}$ & 0.0823 \\
\hline Bulgaria & $0.4681^{\star \star}$ & 0.0433 & 0.0342 & 0.7191 & $6.4336^{\star \star \star}$ & 0.0055 & $-2.4894^{\star \star}$ & 0.0282 \\
\hline China & $0.4678^{\star *}$ & 0.0434 & $0.2981^{\star \star}$ & 0.0215 & $-0.7991^{\star \star}$ & 0.0312 & $0.9225^{\star \star \star}$ & 0.0000 \\
\hline Colombia & $-0.3776^{\star}$ & 0.0770 & -0.0300 & 0.5990 & $-1.4827^{\star \star}$ & 0.0124 & $1.8197^{\star \star \star}$ & 0.0000 \\
\hline Cambodia & $-0.2455^{\star}$ & 0.0819 & 0.1327 & 0.3902 & $-3.0042^{\star \star \star}$ & 0.0009 & $2.7214^{\star \star \star}$ & 0.0001 \\
\hline Croatia & $-0.0696^{\star \star \star}$ & 0.0044 & 0.0069 & 0.5516 & $-0.8947^{\star \star \star}$ & 0.0000 & $1.2395^{\star \star \star}$ & 0.0000 \\
\hline Czech Rep. & 0.1161 & 0.6007 & -0.0394 & 0.6379 & $4.1266^{\star \star \star}$ & 0.0001 & $-1.0312^{\star \star \star}$ & 0.0073 \\
\hline Egypt & $0.3573^{\star \star}$ & 0.0408 & $0.0831^{\star \star}$ & 0.0130 & $-2.6526^{\star \star \star}$ & 0.0000 & $2.0737^{\star \star \star}$ & 0.0000 \\
\hline Estonia & $1.3629^{\star}$ & 0.0889 & $-0.7375^{\star \star \star}$ & 0.0032 & -1.0089 & 0.3141 & $0.8618^{* *}$ & 0.0374 \\
\hline Ethiopia & $0.7807^{\star \star \star}$ & 0.0001 & -0.0223 & 0.4421 & -0.7248 & 0.1030 & $1.0791^{\star \star \star}$ & 0.0001 \\
\hline Georgia & $-0.9889^{\star \star \star *}$ & 0.0008 & $-0.3545^{\star \star \star}$ & 0.0012 & $-3.6845^{\star \star \star}$ & 0.0019 & $3.3140^{\star \star \star}$ & 0.0002 \\
\hline Hungary & $0.7980^{\star \star \star}$ & 0.0010 & -0.0308 & 0.5344 & $3.2989^{\star \star \star}$ & 0.0034 & $-1.0668^{\star *}$ & 0.0335 \\
\hline India & $0.2181^{\star \star \star}$ & 0.0029 & -0.0023 & 0.8276 & $-1.4213^{\star \star \star}$ & 0.0000 & $1.0127^{\star \star \star}$ & 0.0000 \\
\hline Indonesia & $0.1093^{\star \star}$ & 0.0397 & $-0.0280^{\star *}$ & 0.0317 & $0.4138^{\star \star \star}$ & 0.0016 & $0.5785^{\star \star \star}$ & 0.0000 \\
\hline Iran & -0.1326 & 0.3161 & $-0.0435^{\star \star}$ & 0.0253 & $1.4315^{\star \star \star}$ & 0.0000 & $0.3195^{\star *}$ & 0.0463 \\
\hline Iraq & 0.0117 & 0.8914 & -0.0063 & 0.9015 & $1.8473^{\star \star \star}$ & 0.0055 & 0.0186 & 0.9448 \\
\hline Israel & $-0.4225^{\star}$ & 0.0981 & -0.0376 & 0.3562 & $1.5390^{\star \star \star}$ & 0.0009 & $-0.5118^{\star *}$ & 0.0387 \\
\hline Jordan & $-0.7166^{\star \star}$ & 0.0291 & $-0.0388^{* *}$ & 0.0130 & $-1.8655^{\star \star}$ & 0.0354 & $2.2535^{\star \star \star}$ & 0.0022 \\
\hline Kazakhstan & -0.0915 & 0.3500 & $0.3501^{\star \star}$ & 0.0332 & $-1.8871^{\star}$ & 0.0827 & $1.7223^{\star \star \star}$ & 0.0030 \\
\hline South Korea & $-0.4010^{\star \star \star *}$ & 0.0046 & $0.0841^{\star *}$ & 0.0314 & $1.1251^{\star \star \star}$ & 0.0095 & $0.6621^{\star \star *}$ & 0.0061 \\
\hline Kuwait & $-0.7327^{\star *}$ & 0.0165 & 0.0091 & 0.7834 & -0.1497 & 0.8869 & $1.2166^{\star \star \star}$ & 0.0019 \\
\hline Kyrgyz Rep. & $0.3049^{\star \star \star *}$ & 0.0000 & -0.0207 & 0.3407 & -0.2731 & 0.2535 & $0.9982^{\star \star \star}$ & 0.0000 \\
\hline Lebanon & $0.2517^{\star \star}$ & 0.0108 & 0.0860 & 0.5349 & $-2.4695^{\star \star \star}$ & 0.0030 & $1.0084^{\star \star \star}$ & 0.0072 \\
\hline Macedonia & $0.3562^{\star \star \star}$ & 0.0008 & 0.0165 & 0.4020 & $1.7830^{\star \star \star}$ & 0.0042 & $-2.3547^{\star \star \star}$ & 0.0025 \\
\hline Malaysia & -0.0136 & 0.8386 & -0.0047 & 0.7112 & $0.6779^{\star \star \star}$ & 0.0039 & $0.8006^{\star \star \star}$ & 0.0000 \\
\hline Moldova & $-2.4060^{\star}$ & 0.0571 & 0.1156 & 0.4744 & 0.1842 & 0.4789 & $1.9973^{\star *}$ & 0.0139 \\
\hline Mongolia & $0.1825^{\star}$ & 0.0907 & -0.0755 & 0.1863 & 0.4534 & 0.2442 & $0.6323^{\star \star}$ & 0.0132 \\
\hline Morocco & -0.0659 & 0.7002 & -0.0258 & 0.1520 & $1.2431^{\star \star \star}$ & 0.0001 & 0.3640 & 0.1845 \\
\hline Myanmar & -0.0231 & 0.8949 & $0.1214^{\star \star}$ & 0.0201 & $1.7726^{\star \star \star}$ & 0.0000 & -0.0719 & 0.3785 \\
\hline Nepal & -0.2557 & 0.3636 & 0.0197 & 0.6366 & $2.6426^{\star}$ & 0.0937 & -0.4287 & 0.5985 \\
\hline New Zealand & $-0.4121^{\star \star \star}$ & 0.0000 & 0.0038 & 0.3965 & $2.2039^{\star \star \star}$ & 0.0000 & 0.0717 & 0.3280 \\
\hline Oman & $-0.4863^{\star}$ & 0.0661 & -0.0020 & 0.9784 & $3.8912^{\star \star}$ & 0.0133 & -0.5870 & 0.2863 \\
\hline Pakistan & $0.4177^{\star \star \star}$ & 0.0006 & -0.0173 & 0.4119 & $1.3048^{\star \star \star}$ & 0.0019 & -0.0785 & 0.7629 \\
\hline Panama & 0.0884 & 0.5818 & -0.0293 & 0.5242 & $1.7268^{\star \star \star}$ & 0.0002 & -0.0817 & 0.6062 \\
\hline Philippines & 0.2548 & 0.1965 & 0.0552 & 0.5554 & $-1.1682^{\star}$ & 0.0782 & $0.7565^{* *}$ & 0.0156 \\
\hline Poland & $0.2457^{\star \star \star}$ & 0.0089 & $-0.1048^{\star \star \star}$ & 0.0012 & $1.2551^{\star \star \star}$ & 0.0095 & $-0.8055^{\star \star \star}$ & 0.0033 \\
\hline Qatar & 0.0304 & 0.8931 & -0.0669 & 0.1449 & $-2.4103^{\star \star}$ & 0.0398 & $0.7135^{\star \star}$ & 0.0210 \\
\hline Romania & $-0.7288^{\star \star \star *}$ & 0.0002 & -0.0011 & 0.9861 & $-4.4001^{\star \star}$ & 0.0185 & $3.2328^{\star \star \star}$ & 0.0024 \\
\hline Russia & $0.1352^{\star \star \star}$ & 0.0089 & -0.0013 & 0.9033 & $0.3712^{\star}$ & 0.0596 & $0.5674^{\star \star \star}$ & 0.0000 \\
\hline Saudi Arabia & -0.0137 & 0.2044 & -0.0004 & 0.9497 & $1.8046^{\star \star \star}$ & 0.0000 & $0.4647^{\star \star}$ & 0.0146 \\
\hline Singapore & $-0.4688^{\star}$ & 0.0614 & 0.1135 & 0.5951 & $4.7801^{\star \star \star}$ & 0.0010 & $-1.0130^{* *}$ & 0.0399 \\
\hline Slovak Rep. & $0.6278^{\star \star \star}$ & 0.0000 & -0.0042 & 0.8644 & $1.4772^{\star \star \star}$ & 0.0000 & -0.1006 & 0.2305 \\
\hline Slovenia & $0.1069^{\star \star \star}$ & 0.0011 & -0.0016 & 0.7747 & $0.3607^{\star \star \star}$ & 0.0000 & $0.3633^{\star \star \star}$ & 0.0000 \\
\hline South Africa & -2.4824 & 0.1303 & 0.0988 & 0.1025 & 1.3170 & 0.2109 & $4.9394^{\star \star \star}$ & 0.0042 \\
\hline Sri Lanka & $0.1932^{\star}$ & 0.0985 & 0.0136 & 0.7070 & $-0.3724^{\star}$ & 0.0647 & $0.3922^{\star \star \star}$ & 0.0000 \\
\hline Tajikistan & $0.3111^{\star \star \star}$ & 0.0022 & $0.0873^{\star \star \star}$ & 0.0053 & $-1.3176^{\star \star \star}$ & 0.0003 & $0.6149^{\star \star \star}$ & 0.0007 \\
\hline Thailand & -0.0690 & 0.4265 & 0.0368 & 0.2383 & $1.1111^{\star \star \star}$ & 0.0013 & $1.1386^{\star \star \star}$ & 0.0006 \\
\hline Turkey & $0.2063^{\star \star}$ & 0.0474 & -0.0176 & 0.4879 & $-0.8752^{\star \star}$ & 0.0189 & $0.8138^{\star \star \star}$ & 0.0000 \\
\hline Ukraine & $-0.3238^{\star \star \star}$ & 0.0010 & -0.0457 & 0.4561 & -0.0749 & 0.7807 & $1.2236^{\star \star \star}$ & 0.0000 \\
\hline UAE & $-0.4139^{\star}$ & 0.0598 & $-0.0946^{\star \star \star}$ & 0.0005 & $2.0681^{\star \star}$ & 0.0231 & 0.1857 & 0.4243 \\
\hline Vietnam & 0.0933 & 0.3175 & -0.1675 & 0.1164 & $8.2766^{\star \star \star}$ & 0.0071 & $-3.7070^{\star *}$ & 0.0186 \\
\hline Yemen Rep. & $0.5810^{\star \star \star}$ & 0.0001 & $0.1523^{\star *}$ & 0.0150 & $-8.3763^{\star \star \star *}$ & 0.0013 & $8.9006^{\star \star \star}$ & 0.0000 \\
\hline
\end{tabular}

Note; ${ }^{* *},{ }^{* *},{ }^{*}$ indicate the level of significance at 1, 5 and $10 \%$ respectively. 


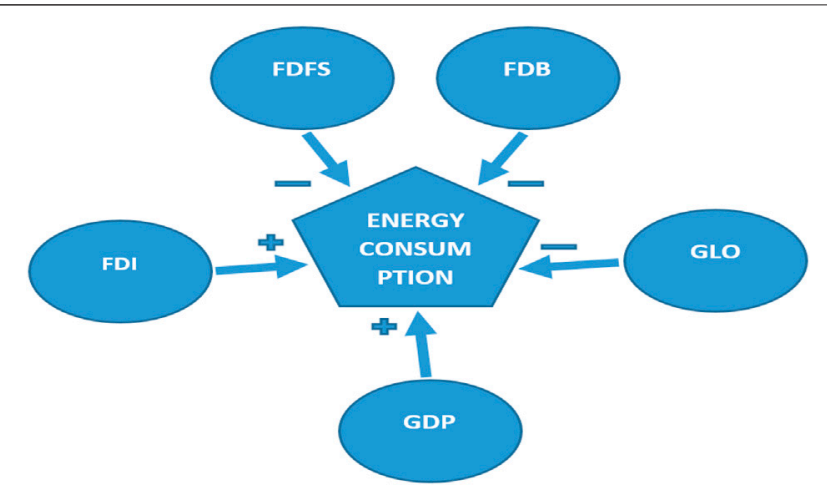

FIGURE 1 | Graphical representation of the long-run results.

use of advanced energy-efficient technologies in production processes or to unsuitable improvement in the total factors of production together with economic growth. High economic growth determines high energy demand for the production of goods and services if advanced or energy-efficient technologies are not implied in the production process (Shahbaz and Lean, 2012).

Further, globalization assists the transfer of innovative technologies from across borders, i.e., from developed countries towards developing countries. It brings an innovative production method rather than conventional production methods and increases the comparative advantages among various nations. More openness through globalization to the international market brings new partners and advances and energy-efficient technology, which also shield the environment from degradation. Globalization through foreign trade and FDI inflows brings energy-efficient machinery, production methods, and managerial skills, which boost economic development and efficient use of energy (Saud et al., 2020) (Figure 1).

The reported results in Table 6, drawn from this study, are reliable and robust, as this study employed additional sensitivity and robustness tests. The results drawn from the various models (i.e., DSUR and PMG ARDL) used, and the different measures used for financial development are robust, as the results are similar across all the models. Further, this study uses the most extended available dataset for the explanatory variables for the BRI panel countries. Table 6 shows the robustness of DSUR estimation.

\section{Results From DOLS (Country-Wise Analysis)}

After analyzing the long-run estimation for panel data, it is imperative to comprehend the dynamic nexus between FDI, EC and FD across individual countries. The fully modified ordinary least squares model (FMOLS) is applied to analyze the long-run country-wise analysis of the data. The results of DOLS estimations are presented in Table 7. The finding implies that FD has a positive and significant impact on EC in 25 countries (Armenia, Azerbaijan, Bahrain, Belarus, Bulgaria, China, Egypt, Estonia, Ethiopia, Hungary, India, Indonesia,
Kyrgyz Republic, Lebanon, Macedonia, Mongolia, Pakistan, Poland, Russia, Slovak Republic, Slovenia, Sri Lanka, Tajikistan, Turkey, and the Yemen Republic). This finding implies that FD positively stimulates the consumption of energy in these countries.

It is recommended in regard to policy implications in these countries that they enhance the introduction of high energy energy-efficient technology through FD in the financial and banking sectors. Further, financial institutions should invest more in energy-efficient projects and $\mathrm{R} \& \mathrm{D}$ to boost efficient production and consumption of energy. On the other hand, it is observed that FD has an adverse influence on EC in 16 countries (Brunei Darussalam, Colombia, Cambodia, Croatia, Georgia, Israel, Jordan, Republic of Korea, Kuwait, Moldova, New Zealand, Oman, Romania, Singapore, Ukraine, and the UAE).

The development of the financial sector is positively contributing towards efficient use of energy or through energy conservation policies. Policymakers need to keep constant or to further improve such energy conservation policies in the future. An insignificant relationship was observed in 18 countries (Albania, Bangladesh, Bosnia Herzegovina, Czech Republic, Iran, Iraq, Kazakhstan, Malaysia, Morocco, Myanmar, Nepal, Panama, Philippines, Qatar, Saudi Arabia, South Africa, Thailand, and Vietnam).

The coefficient of FDI has a significant positive impact on energy consumption in ten BRI countries (Armenia, Azerbaijan, Bahrain, China, Egypt, Kazakhstan, South Korea, Myanmar, Tajikistan, and the Yemen Republic). This result implies that high EC encourages more investment and growth activities, which call for further financial development in the regions (Shahbaz and Lean, 2012). To reduce high EC, strict rules and policies regarding FDI inflow are needed in these countries. High tariffs on the introduction of old and high EC technology can help to reduce high $\mathrm{EC}$ in these economies, unlike the negative and significant impact of FDI on EC found in eleven BRI countries (Albania, Belarus, Bosnia and Herzegovina, Brunei Darussalam, Estonia, Georgia, Indonesia, Iran, Jordan, Poland, and the UAE). This means that FDI inflow into these countries brings energyefficient technology, knowledge, and skills to the host country.

In contrast, an insignificant impact was observed in $38 \mathrm{BRI}$ countries (Bangladesh, Bulgaria, Colombia, Cambodia, Croatia, Czech Republic, Ethiopia, Hungary, India, Iraq, Israel, Kuwait, Kyrgyz Republic, Lebanon, Malaysia, Macedonia, Mongolia, Moldova, Morocco, New Zealand, Nepal, Oman, Panama, Pakistan, Philippines, Qatar, Russia, Romania, Singapore, Saudi Arabia, Slovenia, Slovak Republic, Sri Lanka, South Africa, Turkey, Thailand, Ukraine, and Vietnam).

In regard to the estimated coefficient of globalization, EC was found to be significant and positive in 30 BRI countries (Azerbaijan, Belarus, Bosnia and Herzegovina, Brunei Darussalam, Bulgaria, Czech Republic, Hungary, Indonesia, Iran, Iraq, Israel, South Korea, Macedonia, Malaysia, Morocco, Myanmar, New Zealand, Nepal, Oman, Pakistan, Poland, Panama, Russia, Singapore, Saudi Arabia, Slovenia, Slovak Republic, Thailand, UAE, and Vietnam). This finding implies that an increase in globalization causes high EC. This may be due 
TABLE 8 | Results of Dumitrescu-Hurlin (DH) panel causality.

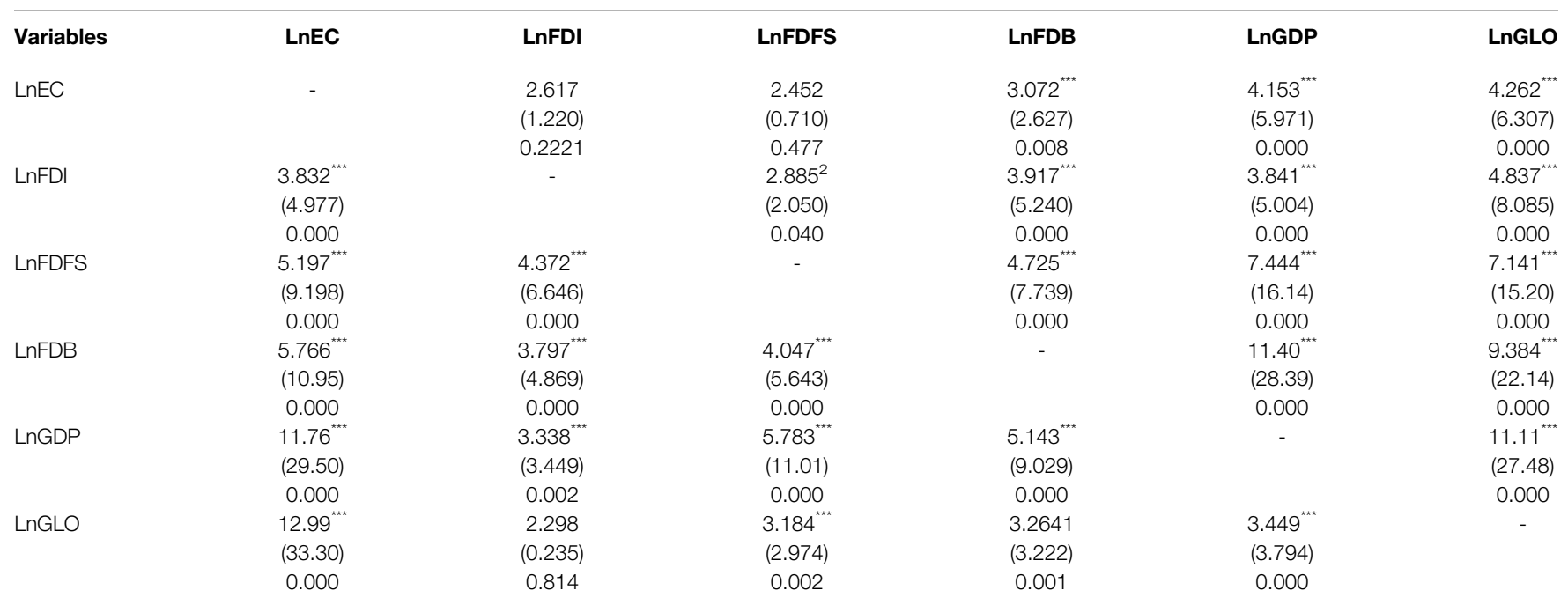

Note: Null hypothesis: No causality, top values represent W-statistics, () represents Z-statistics, ${ }^{* * *}$, and ${ }^{* *}$ represent 1 and $5 \%$ levels of significance.

to inefficient EC technology transfer through globalization. It strongly suggests that governments should take initiatives to establish strict policies regarding FDI inflows and trade. Further, high taxes on old and outdated high EC technologies are required in order to reduce energy consumption.

Unlike the finding above, globalization also has a negative and significant impact on EC in 20 BRI countries (Armenia, Bahrain, Bangladesh, China, Colombia, Cambodia, Croatia, Egypt, Georgia, India, Jordan, Kazakhstan, Lebanon, Philippines, Qatar, Romania, Sri Lanka, Tajikistan, Turkey, and Yemen Republic). At the same time, an insignificant nexus was observed in nine countries (Albania, Estonia, Ethiopia, Kuwait, Kyrgyz Republic, Moldova, Mongolia, South Africa, and Ukraine).

Economic growth had a significant positive impact on EC in 39 BRI countries (Armenia, Albania, Bahrain, Bosnia and Herzegovina, Bangladesh, Brunei Darussalam, China, Cambodia, Colombia, Croatia, Estonia, Egypt, Ethiopia, Georgia, India, Iran, Indonesia, Jordan, Kazakhstan, Kyrgyz Republic, Kuwait, South Korea, Lebanon, Moldova, Malaysia, Mongolia, Qatar, Philippines, Romania, Russia, Sri Lanka, Saudi Arabia, Slovenia, South Africa, Thailand, Tajikistan, Turkey, Ukraine, and the Yemen Republic). This result implies that these BFRI countries are energy-dependent, and therefore energy conservation policies are needed to address high EC. High EC leads to high increased economic growth; consequently, the efficient utilization of energy is required to maintain high economic growth with low EC. Hence, the escalation in EC leads to increased growth and investments in these regions.

Unlike this result above, economic growth also adversely influences EC in ten BRI countries (Azerbaijan, Belarus, Bulgaria, Czech Republic, Hungary, Israel, Macedonia, Poland, Singapore, and Vietnam). This implies that these countries have achieved efficiency in economic growth along with efficient utilization of energy.

Finally, insignificant impact has been found in ten BRI countries (Iraq, Myanmar, Morocco, New Zealand, Nepal, Oman, Panama, Pakistan, UAE, and the Slovak Republic).

\section{Dumitrescu Hurlin Panel Causality}

The empirical results from Table 8 imply the presence of a feedback hypothesis between FD and EC. A similar result is also found by prior empirical works, for instance, Farhani and Solarin (2017), for the US, Bekhet et al. (2017), for GCC countries, and Shahbaz et al. (2013) for Malaysia. This implies FD assistance in providing easy loans or debt for the establishment of new businesses, investment activities, or purchasing durable EC goods. The rise in EC enhances economic expansion, resulting in a rise in demand for financial services, which further guarantees FD. The finding implies that FD and EC are complementary (Islam et al., 2013a). Our study supports a two-way causal link between GDP and EC. This finding is similar to Shahbaz et al. (2013) for Malaysia, Kahouli (2017), for SMCs, and Ahmed (2017) for BRICS. It implies that EC and GDP impact each other, which suggests that EC- and GDP-related policies should be implemented mutually. The causality results indicate a mutually reinforcing (feedback) effect between FD and GDP. This finding validates the demand-supply side hypothesis and is similar to the finding reached by Shahbaz et al. (2013). FD enhances capital formation, opens up opportunities for entrepreneurs, stimulates trade, and offers financial resources with low costs, motivating foreign investors to invest in the home country, and resulting in enhancement of domestic output. Thus, a rise of economic growth occurs (Shahbaz et al., 2017a). A two-way causal association is detected between GDP and FD. Similar results were found by Almulali and Lee (2013) for GCC countries and Islam et al. (2013c) for Malaysia.

The bidirectional causal relationship is observed between globalization and FD, globalization and GDP, GDP and FDI, FDI and FD, and globalization and EC. However, it differs in regard to a unidirectional causal link detected from EC towards FD. This result is similar to the finding reached by Tang and Tan (2014) and Furuoka (2015); they show that energy conservation policies should be implemented. Similarly, a one-way causal relationship was detected running from EC to FDI. 


\section{CONCLUSION AND POLICY RECOMMENDATIONS}

The study investigates the nexus between foreign direct investment, financial development, energy consumption, economic growth, and globalization for 59 BRI countries over 1990-2016. This study implements the Pesaran, $\mathrm{LM}$ and $\mathrm{CD}$ tests to find heterogeneity and $\mathrm{CD}$ dependency across country variables, and CIPS and CADF panel unit root tests to gauge the stationarity of the data, the Westerlund panel co-integration test to investigate the long-run association among the studied variables, the DSUR panel approach to analyze long-run panel estimation, the DOLS panel approach to examine long-run country-wise analysis, and Dumitrescu Hurlin panel causality approach to explore the presence of the causal links between the analyzed variables.

The main impetus for this study is the absence of empirical work that observes the nexus between financial development, foreign direct investment and energy consumption based on sources from BRI countries. This study employs secondgeneration estimations, along with two different proxies for financial development measures. Hence, the results of this study are more robust and reliable.

The overall findings of the study, together with policy recommendation, are as follows.

- By applying $\mathrm{CD}$ tests, the study revealed heterogeneity and $\mathrm{CD}$ dependency across countries for the analyzed variables dataset.

- The CADF and CIPS unit root test determines that all the analyzed variables are stationary at first differences [I(1)] and non-stationary at their level.

- The Westerlund co-integration test results show the presence of long-run co-integration among the analyzed variables.

- The DSUR estimator reports that both FDI and economic growth lead to an escalation in energy consumption. On the other hand, financial development and globalization decrease energy consumption in BRI countries.

- The results drawn from the DOLS estimator show that FD has a positive impact on EC in 25 countries and a negative impact on EC in 16 countries. Similarly, the estimated coefficient of FDI has a significant positive effect on EC in ten countries and negatively impacts EC in 11 countries. In regard to the estimated coefficient of globalization and EC, this was found to be substantial and positive in 30 countries, but negatively influences EC in 20 economies. GDP has a positive and meaningful relationship with EC in 39 countries and a negative relationship in ten countries.

- The DH panel causality test results report the existence of a two-way causal relationship between EC and FD, FDI and

\section{REFERENCES}

Adebayo, T. S., Awosusi, A. A., Kirikkaleli, D., Akinsola, G. D., and Mwamba, M. N. (2021). Can CO 2 Emissions and Energy Consumption Determine the Economic Performance of South Korea? A Time Series Analysis. Environ. Sci. Pollut. Res., 28(29):38969-38984. doi:10.1007/s11356-02113498-1
FD, EC and GDP, and GLO and EC in the long run. There is enough evidence to support the one-way Granger causal relationship running from EC towards FD and FDI.

To reduce EC in the long run, high EC countries need to specialize in production of non-energy-intensive products. Efficient energy use will enhance production activities, along with economic development, in selected BRI countries. Energy-intensive industries and firms need to follow strict energy-efficient consumption regulations. Financial institutions should invest more in energy-efficient technology, efficient EC projects, and R\&D-related programs. Further, the encouragement of advanced technology through foreign investment and an increase in tariffs on old and outdated technologies will also reduce high EC in these countries.

More openness to international markets brings advances and innovative energy-efficient technology and techniques to the regions. Globalization through FDI brings new partners and flexibilities in the production line with new investments, which lead to efficient energy use. This diffusion of the foreign investment wave's energy-efficient consumption with new technology and efficient use of raw materials products consequently reduces energy misuse. Further, international liberalization and FDI inflows bring positive externalities to society and raise public awareness regarding the efficient utilization of energy, which is also an important step to mitigate energy consumption.

\section{DATA AVAILABILITY STATEMENT}

Publicly available datasets were analyzed in this study. This data can be found here: www.databank.worldbank.org.

\section{AUTHOR CONTRIBUTIONS}

All authors listed have made a substantial, direct, and intellectual contribution to the work and approved it for publication.

\section{FUNDING}

This research is supported by the National Social Science Fund (19BGL127), the National Natural Science Fund (71572071 \& 72072076), the Humanities and Social Sciences Fund of the Ministry of Education China (18YJA630074) and partial support from ILMA University, Karachi, Pakistan.

Adebayo, T. S., Kirikkaleli, D., Adeshola, I., Oluwajana, D., Akinsola, G. D., and Osemeahon, O. S. (2021). Coal Consumption and Environmental Sustainability in South Africa: The Role of Financial Development and Globalization. Int. J. Renew. Energ. Dev. 10 (3). doi:10.14710/ijred.0.34982

Adebayo, T. S., and Kirikkaleli, D. (2021). Impact of Renewable Energy Consumption, Globalization, and Technological Innovation on Environmental Degradation in Japan: Application of Wavelet Tools. Environ. Dev. Sustainability, 1-26. doi:10.1007/s10668-021-01322-2 
Adebayo, T. S., Ramzan, M., Iqbal, H. A., Awosusi, A. A., and Akinsola, G. D. (2021). The Environmental Sustainability Effects of Financial Development and Urbanization in Latin American Countries. Environ. Sci. Pollut. Res., 1-14. doi:10.1007/s11356-021-14580-4

Ahmed, K. (2017). Revisiting the Role of Financial Development for EnergyGrowth-Trade Nexus in BRICS Economies. Energy 128, 487-495. doi:10.1016/ j.energy.2017.04.055

Al-mulali, U., and Lee, J. Y. M. (2013). Estimating the Impact of the Financial Development on Energy Consumption: Evidence from the GCC (Gulf Cooperation Council) Countries. Energy 60, 215-221. doi:10.1016/ j.energy.2013.07.067

Alam, A., Malik, I. A., Abdullah, A. B., Hassan, A., Faridullah, U. A., Awan, U., et al. (2015). Does Financial Development Contribute to SAARC'S Energy Demand? from Energy Crisis to Energy Reforms. Renew. Sustain. Energ. Rev. 41, 818-829. doi:10.1016/j.rser.2014.08.071

Baloch, M. A., Ozturk, I., Bekun, F. V., and Khan, D. (2021). Modeling the Dynamic Linkage between Financial Development, Energy Innovation, and Environmental Quality: Does Globalization Matter?. Bus Strat Env 30 (1), 176-184. doi:10.1002/bse.2615

Bekhet, H. A., Matar, A., and Yasmin, T. (2017). CO 2 Emissions, Energy Consumption, Economic Growth, and Financial Development in GCC Countries: Dynamic Simultaneous Equation Models. Renew. Sustain. Energ. Rev. 70, 117-132. doi:10.1016/j.rser.2016.11.089

Belke, A., Dobnik, F., and Dreger, C. (2011). Energy Consumption and Economic Growth: New Insights into the Cointegration Relationship. Energ. Econ. 33, 782-789. doi:10.1016/j.eneco.2011.02.005

Chang, S.-C. (2015). Effects of Financial Developments and Income on Energy Consumption. Int. Rev. Econ. Finance 35, 28-44. doi:10.1016/j.iref.2014.08.011

Çoban, S., and Topcu, M. (2013). The Nexus between Financial Development and Energy Consumption in the EU: A Dynamic Panel Data Analysis. Energ. Econ. 39, 81-88. doi:10.1016/j.eneco.2013.04.001

Doytch, N., and Narayan, S. (2016). Does FDI Influence Renewable Energy Consumption? an Analysis of Sectoral FDI Impact on Renewable and Nonrenewable Industrial Energy Consumption. Energ. Econ. 54, 291-301. doi:10.1016/j.eneco.2015.12.010

Dumitrescu, E.-I., and Hurlin, C. (2012). Testing for Granger Non-causality in Heterogeneous Panels. Econ. Model. 29, 1450-1460. doi:10.1016/ j.econmod.2012.02.014

Fan, L. W., Pan, S. J., Liu, G. Q., and Zhou, P. (2017). Does Energy Efficiency Affect Financial Performance? Evidence from Chinese Energy-Intensive Firms. J. Clean. Prod. 151, 53-59. doi:10.1016/j.jclepro.2017.03.044

Farhani, S., and Solarin, S. A. (2017). Financial Development and Energy Demand in the United States: New Evidence from Combined Cointegration and Asymmetric Causality Tests. Energy 134, 1029-1037. doi:10.1016/ j.energy.2017.06.121

Furuoka, F. (2015). Electricity Consumption and Economic Development in Asia: New Data and New Methods. Asia Pac. Econ. Lit. 29, 102-125. doi:10.1111/apel.12093

Godement, F. (2015). “ONE BELT, ONE ROAD”: CHINA'S GREAT LEAP OUTWARD.

Godil, D. I., Sharif, A., Ali, M. I., Ozturk, I., and Usman, R. (2021). The Role of Financial Development, R\&D Expenditure, Globalization and Institutional Quality in Energy Consumption in India: New Evidence from the QARDL Approach. J. Environ. Manage. 285, 112208. doi:10.1016/j.jenvman.2021.112208

Han, L., Han, B., Shi, X., Su, B., Lvv, X., Lei, X., et al. (2018). Energy Efficiency Convergence across Countries in the Context of China's Belt and Road Initiative. Appl. Energ. 213, 112-122. doi:10.1016/ j.apenergy.2018.01.030

Haseeb, A., Xia, E., Saud, S., Ahmad, A., and Khurshid, H. (2019). Does Information and Communication Technologies Improve Environmental Quality in the Era of Globalization? an Empirical Analysis. Environ. Sci. Pollut. Res. 26 (9), 8594-8608. doi:10.1007/s11356-019-04296-x

He, X., Adebayo, T. S., Kirikkaleli, D., and Umar, M. (2021). Consumption-based Carbon Emissions in Mexico: An Analysis Using the Dual Adjustment Approach. Sustainable Prod. Consumption 27, 947-957. doi:10.1016/ j.spc.2021.02.020

Hu, X., Imran, M., Wu, M., Moon, H. C., and Liu, X. (2020). Alternative to Oil and Gas: Review of Economic Benefits and Potential of Wind Power in Pakistan. Math. Probl. Eng. 2020, 1-16. doi:10.1155/2020/8884228
Husaini, D. H., and Lean, H. H. (2015). Does Electricity Drive the Development of Manufacturing Sector in Malaysia?. Front. Energ. Res. 3, 18. doi:10.3389/ fenrg.2015.00018

Islam, F., Shahbaz, M., Ahmed, A. U., and Alam, M. M. (2013a). Financial Development and Energy Consumption Nexus in Malaysia: A Multivariate Time Series Analysis. Econ. Model. 30, 435-441. doi:10.1016/ j.econmod.2012.09.033

Islam, F., Shahbaz, M., Ahmed, A. U., and Alam, M. M. (2013c). Financial Development and Energy Consumption Nexus in Malaysia: A Multivariate Time Series Analysis. Econ. Model. 30:435-441. doi:10.1016/ j.econmod.2012.09.033

Kahouli, B. (2017). The Short and Long Run Causality Relationship Among Economic Growth, Energy Consumption and Financial Development: Evidence from South Mediterranean Countries (SMCs). Energ. Econ. 68, 19-30. doi:10.1016/j.eneco.2017.09.013

Khan, M. A., and Ozturk, I. (2020). Examining Foreign Direct Investment and Environmental Pollution Linkage in Asia. Environ. Sci. Pollut. Res. 27 (7), 7244-7255. doi:10.1007/s11356-019-07387-x

Kirikkaleli, D., Adebayo, T. S., Khan, Z., and Ali, S. (2021). Does Globalization Matter for Ecological Footprint in Turkey? Evidence from Dual Adjustment Approach. Environ. Sci. Pollut. Res. 28 (11), 14009-14017. doi:10.1007/s11356020-11654-7

Komal, R., and Abbas, F. (2015). Linking Financial Development, Economic Growth and Energy Consumption in Pakistan. Renew. Sustain. Energ. Rev. 44, 211-220. doi:10.1016/j.rser.2014.12.015

Krane, J. (2018). KraneShares and CICC to Host One Belt One Road Summit at NYSE.

Le, H. P., and Ozturk, I. (2020). The Impacts of Globalization, Financial Development, Government Expenditures, and Institutional Quality on CO2 Emissions in the Presence of Environmental Kuznets Curve. Environ. Sci. Pollut. Res. 27 (18), 22680-22697. doi:10.1007/s11356-020-08812-2

Lee, J. W., and Wan, J. (2013). The Contribution of Foreign Direct Investment to Clean Energy Use, Carbon Emissions and Economic Growth. Energy Policy 55, 483-489. doi:10.1016/j.enpol.2012.12.039

Li, S., Zhao, L., and Shen, H. (2021). Foreign Direct Investment and Institutional Environment: the Impact of Bilateral Investment Treaties. Appl. Econ., 1-14. doi:10.1080/00036846.2021.1883535

Ling, C. H., Ahmed, K., Binti Muhamad, R., and Shahbaz, M. (2015). Decomposing the Trade-Environment Nexus for Malaysia: what Do the Technique, Scale, Composition, and Comparative Advantage Effect Indicate?. Environ. Sci. Pollut. Res. 22, 20131-20142. doi:10.1007/s11356-015-5217-9

Liu, L., Zhou, C., Huang, J., and Hao, Y. (2018). The Impact of Financial Development on Energy Demand: Evidence from China. Emerging Markets Finance and Trade 54, 269-287. doi:10.1080/ 1540496X.2017.1358609

Long, X., Chen, Y., Du, J., Oh, K., and Han, I. (2017). Environmental Innovation and its Impact on Economic and Environmental Performance: Evidence from Korean-owned Firms in China. Energy Policy 107, 131-137. doi:10.1016/ j.enpol.2017.04.044

Mahalik, M. K., Babu, M. S., Loganathan, N., and Shahbaz, M. (2017). Does Financial Development Intensify Energy Consumption in Saudi Arabia?. Renew. Sustain. Energ. Rev. 75, 1022-1034. doi:10.1016/j.rser.2016.11.081

Mark, N. C., Ogaki, M., and Sul, D. (2005). Dynamic Seemingly Unrelated Cointegrating Regressions. Rev. Econ. Stud. 72, 797-820. doi:10.1111/j.1467937x.2005.00352.x

Nasreen, S., Anwar, S., and Ozturk, I. (2017). Financial Stability, Energy Consumption and Environmental Quality: Evidence from South Asian Economies. Renew. Sustain. Energ. ReviewsRev 67, 1105-1122. doi:10.1016/ j.rser.2016.09.021

NDRC NOFA M (2015). "Vision and Actions on Jointly Building Silk Road Economic Belt and 21st-Century Maritime Silk Road," in Affairs, and Ministry of Commerce of the People's Republic of China (Beijing: National Development and Reform Commission, Ministry of Foreign).

O'Connell, P. G. J. (1998). The Overvaluation of Purchasing Power Parity. J. Int. Econ. 44, 1-19. doi:10.1016/S0022-1996(97)00017-2

Ozturk, I., and Acaravci, A. (2013). The Long-Run and Causal Analysis of Energy, Growth, Openness and Financial Development on Carbon Emissions in Turkey. Energ. Econ. 36, 262-267. doi:10.1016/j.eneco.2012.08.025 
Palit, A. (2017). India's Economic and Strategic Perceptions of China's Maritime Silk Road Initiative. Geopolitics 22, 292-309. doi:10.1080/ 14650045.2016.1274305

Pesaran, M. H. (2007). A Simple Panel Unit Root Test in the Presence of CrossSection Dependence. J. Appl. Econ. 22, 265-312. doi:10.1002/jae10.1002/jae.951

Pesaran, M. H., Ullah, A., and Yamagata, T. (2008). A Bias-Adjusted LM Test of Error Cross-Section independence. Econom. J. 11, 105-127. doi:10.1111/j.1368423X.2007.00227.x

Pieter, B. (2017). Where Will China's "One Belt, One Road" Initiative Leads?. Available at: http://knowledge.wharton.upenn.edu/article/can-chinas-one-beltone-road-initiative-match-the-hype/.

Pohekar, S. D., and Ramachandran, M. (2004). Application of Multi-Criteria Decision Making to Sustainable Energy Planning-A Review. Renew. Sustain. Energ. Rev. 8, 365-381. doi:10.1016/j.rser.2003.12.007

Rehman, A., Ma, H., Ahmad, M., Ozturk, I., and Işık, C. (2021). Estimating the Connection of Information Technology, Foreign Direct Investment, Trade, Renewable Energy and Economic Progress in Pakistan: Evidence from ARDL Approach and Cointegrating Regression Analysis. Environ. Sci. Pollut. Res., 1-13. doi:10.1007/s11356-021-14303-9

Sadorsky, P. (2011). Financial Development and Energy Consumption in Central and Eastern European Frontier Economies. Energy Policy 39, 999-1006. doi:10.1016/j.enpol.2010.11.034

Sadorsky, P. (2010). The Impact of Financial Development on Energy Consumption in Emerging Economies. Energy Policy 38, 2528-2535. doi:10.1016/j.enpol.2009.12.048

Saqib, A., Chan, T. H., Mikhaylov, A., and Lean, H. H. (2021). Are the Responses of Sectoral Energy Imports Asymmetric to Exchange Rate Volatilities in Pakistan? Evidence from Recent Foreign Exchange Regime. Front. Energ. Res. 9, 215. doi:10.3389/fenrg.2021.614463

Saud, S., Chen, S., Haseeb, A., Khan, K., and Imran, M. (2019). The Nexus between Financial Development, Income Level, and Environment in central and Eastern European Countries: a Perspective on belt and Road Initiative. Environ. Sci. Pollut. Res. 26 (16), 16053-16075. doi:10.1007/s11356-019-05004-5

Saud, S., Chen, S., Haseeb, A., and Sumayya (2020). The Role of Financial Development and Globalization in the Environment: Accounting Ecological Footprint Indicators for Selected one-belt-one-road Initiative Countries. J. Clean. Prod. 250, 119518. doi:10.1016/j.jclepro.2019.119518

Saud, S., Danish and Chen, S. (2018). An Empirical Analysis of Financial Development and Energy Demand: Establishing the Role of Globalization. Environ. Sci. Pollut. Res. 25 (24), 24326-24337. doi:10.1007/s11356-018-2488-y

Shahbaz, M., Hoang, T. H. V., Mahalik, M. K., and Roubaud, D. (2017a). Energy Consumption, Financial Development and Economic Growth in India: New Evidence from a Nonlinear and Asymmetric Analysis. Energ. Econ. 63, 199-212. doi:10.1016/j.eneco.2017.01.023

Shahbaz, M., Khan, S., Ali, A., and Bhattacharya, M. (2017b). The Impact of Globalization on CO2 Emissions in China. Singapore Econ. Rev. 62, 929-957. doi:10.1142/S0217590817400331

Shahbaz, M., and Lean, H. H. (2012). Does Financial Development Increase Energy Consumption? the Role of Industrialization and Urbanization in Tunisia. Energy Policy 40, 473-479. doi:10.1016/j.enpol.2011.10.050

Shahbaz, M., Mallick, H., Mahalik, M. K., and Sadorsky, P. (2016b). The Role of Globalization on the Recent Evolution of Energy Demand in India: Implications for Sustainable Development. Energ. Econ. 55, 52-68. doi:10.1016/j.eneco.2016.01.013
Shahbaz, M., Solarin, S. A., Mahmood, H., and Arouri, M. (2013). Does Financial Development Reduce CO2 Emissions in Malaysian Economy? A Time Series Analysis. Econ. Model. 35, 145-152. doi:10.1016/j.econmod.2013.06.037

Shujah-Ur-Rahman, S., Chen, S., Saud, S., Bano, S., and Haseeb, A. (2019). The Nexus between Financial Development, Globalization, and Environmental Degradation: Fresh Evidence from Central and Eastern European Countries. Environ. Sci. Pollut. Res. Int. 26 (24), 24733-24747. doi:10.1007/s11356-01905714-w

Sirin, S. M. (2017). Foreign Direct Investments (FDIs) in Turkish Power Sector: A Discussion on Investments, Opportunities and Risks. Renew. Sustain. Energ. Rev. 78, 1367-1377. doi:10.1016/j.rser.2017.05.160

Solarin, S. A., Al-Mulali, U., Musah, I., and Ozturk, I. (2017). Investigating the Pollution haven Hypothesis in Ghana: An Empirical Investigation. Energy 124, 706-719. doi:10.1016/j.energy.2017.02.089

Sun, H., Mohsin, M., Alharthi, M., and Abbas, Q. (2020). Measuring Environmental Sustainability Performance of South Asia. J. Clean. Prod. 251, 119519. doi:10.1016/j.jclepro.2019.119519

Tamazian, A., Chousa, J. P., and Vadlamannati, K. C. (2009). Does Higher Economic and Financial Development lead to Environmental Degradation: Evidence from BRIC Countries. Energy Policy 37, 246-253. doi:10.1016/j.enpol.2008.08.025

Tang, C. F., and Tan, B. W. (2014). The Linkages Among Energy Consumption, Economic Growth, Relative price, Foreign Direct Investment, and Financial Development in Malaysia. Qual. Quant 48, 781-797. doi:10.1007/s11135-012-9802-4

Teng, J.-Z., Khan, M. K., Khan, M. I., Chishti, M. Z., and Khan, M. O. (2021). Effect of Foreign Direct Investment on CO2 Emission with the Role of Globalization, Institutional Quality with Pooled Mean Group Panel ARDL. Environ. Sci. Pollut. Res. 28 (5), 5271-5282. doi:10.1007/s11356-020-10823-y

Westerlund, J. (2007). Testing for Error Correction in Panel Data. Oxford Bull. Econ. Stats 69, 709-748. doi:10.1111/j.1468-0084.2007.00477.x

$\mathrm{Xu}, \mathrm{S}$. J. (2012). The Impact of Financial Development on Energy Consumption in China: Based on SYS-GMM Estimation. Amr 524-527, 2977-2981. doi:10.4028/ www.scientific.net/amr.524-527.2977

Zhang, Y.-J. (2011). The Impact of Financial Development on Carbon Emissions: An Empirical Analysis in China. Energy Policy 39, 2197-2203. doi:10.1016/ j.enpol.2011.02.026

Conflict of Interest: The authors declare that the research was conducted in the absence of any commercial or financial relationships that could be construed as a potential conflict of interest.

Publisher's Note: All claims expressed in this article are solely those of the authors and do not necessarily represent those of their affiliated organizations, or those of the publisher, the editors and the reviewers. Any product that may be evaluated in this article, or claim that may be made by its manufacturer, is not guaranteed or endorsed by the publisher.

Copyright $\odot 2021$ Lu, Imran, Haseeb, Saud, Wu, Siddiqui and Khan. This is an open-access article distributed under the terms of the Creative Commons Attribution License (CC BY). The use, distribution or reproduction in other forums is permitted, provided the original author(s) and the copyright owner(s) are credited and that the original publication in this journal is cited, in accordance with accepted academic practice. No use, distribution or reproduction is permitted which does not comply with these terms. 